\title{
The Determinants of the Performance and the Sustainability of Conventional and Islamic Microfinance Institutions
}

\author{
Marwa Fersi, Mouna Boujelbéne \\ University of Sfax, Sfax, Tunisia
}

\begin{abstract}
The purpose of this paper is to study the factors determining the performance (organizational, social, and financial) of conventional and Islamic microfinance institutions and their impact on maintaining the sustainability of these institutions. A panel data on a sample of 333 conventional and 49 Islamic microfinance institutions (MFIs) between 1996 and 2012 of six different regions is used for this purpose and analyzes using the simple linear regression technique. The results show that the sustainability measered by operational autonomy (OSS) of Islamic MFIs (IMFIs) is sensitive to their social performance (SP), while the sustainability of Conventional MFIs (CMFIs) is sustained by their Financial Performance (FP) measured by return on assets (ROA). Thus, these latter seem to deviate from the main social objective focusing more on profitability. Indeed, this judgement is confirmed when the results also showed that their (CMFIs) FP is positively affected by the quality of credit portfolios which reveals the category of the targeted clients (the poorest of the poor are abandoned). On the contrary, FP of IMFIs seems to be mainly supported by their specific source of funding through the islamic financial contracts where the results revealed that their profitabilty is positively affected by their capital structure. Moreover, the results show that the organizational performance positively affects the sustainability of the two categories of MFIs.
\end{abstract}

Keywords: conventional microfinance, Islamic microfinance, organizational performance, social performance, financial performance, sustainability

\section{Introduction}

Over the past three decades, microfinance has been considered as an alternative solution for global poverty alleviation (Koveos \& Randhawa, 2004; Shaw, 2004; Brau \& Woller, 2004). It is presented as a solution for sustainable development. The essential role of MFIs is to expand economic opportunities and financial markets to the poor (Copestake, Johnson, \& Wright, 2002; Seibel \& Agung, 2006; Seibel, 2008; Wright \& Copestake, 2004). Thanks to the microfinance mechanism, poor people who are excluded from formal financial system can have access to financial services. Microcredit is considered as the main financial service offered by MFIs. Also, microfinance clients have the opportunity of saving small amounts. Moreover, services like micro-insurance or remittance services are provided by MFIs in the most developed systems.

Poverty focused microfinance institutions based on Islamic principles are lagging behind compared to

Marwa Fersi, Ph.D. student, management science-finance, Faculty of Economics and Management of Sfax, University of Sfax, Sfax, Tunisia.

Mouna Boujelbéne, assistant professor of finance, Faculty of Economics and Management of Sfax, University of Sfax, Sfax, Tunisia.

Correspondence concerning this article should be addressed to Marwa Fersi, Faculty of Economics and Management of Sfax, University of Sfax, Airport Road, 3018-Sfax, Tunisia. 
conventional microfinance institutions (Ahmed, 2002; Segrado, 2005). Sharing the same social and financial objectives, Islamic microfinance brought more variety to this sector. The Islamic microfinance concept was developed as an alternative for Muslim borrowers; based on Islamic financial contracts (Karim, Tarazi, \& Reille, 2008). It offers services respecting the principles of the Islamic law (Sharia). The basic principles of Islam insist strongly on justice, social inclusion, and the sharing resources between rich and poor. Furthermore, Islamic microfinance exceeds the concept of microcredit by including charity in finance, in its Islamic form, i.e. the Zakat (alms) and Waqf (endowment), in order to assist the poor's basic needs and necessities, and to avoid the over indulge of productive loans into consumption purposes (Ahmed, 2007; Wilson, 2007). Zakat represents the third pillar of the Islamic faith. The word Zakat in Arabic means to grow or to increase and when referred to people it means to improve or to become better (Seibel, 2008). An Islamic MFI can exploit the Zakat fund in two different ways. First, after the collection of the recommended amount of Zakat (a percentage usually 2.5\% of the total wealth accumulated in a year) the institution then distributes it to specific group of beneficiaries which are listed in eight different categories in the Holy Quran and this mechanism helps islamic microfinance to reach the poorest of the poor. Thus, the social objective is fulfilled. Second, IMFIs can benefit from Zakat fund for their own good by employing it to cover operating expenses. However, in Islamic legal terminology, Awqaf (plural of Waqf) are used as a form of endowment, where a particular property (an asset) or an income devoted to socio-economic welfare development programs specifically poverty alleviation through different Sharia compliant products (Ahmed, 2007). Furthermore, IMFIs offer a varied package of Sharia-compliant products e.g. the Murabaha contract which is the most prevalent (El-Zoghbi \& Alvarez, 2015) with total portfolio of assets almost US \$ 413 million in 2011 (Nimrah \& Mohammed, 2011). Also, in the second place, "Qard Al-Hasan" an interest free benevolent loan that relies on subsidies and donations, and other Islamic financial products such as Musharaka, Mudaraba, Salam contracts, etc. (Mohammed, 2011). Sharia-compliant products are considered investment instruments (i.e., the Mudaraba and Musharaka contracts) except the Murabaha contract and Qard Al-Hasan, which are the Islamic alternative of regular debt instruments. These instruments could be the solution of substantial Muslim population observing religious prohibition of interest, struggling to avoid common financial products and prefer microfinance products that respect the principles of their faith.

The microfinance industry has expanded remarkably fast (Gonzales, 2010). MFIs strive for financial sustainability but also empowerment of the poor. Sustainability in simple terms refers to the long-term continuation of the microfinance programme and the clients continue to benefit from these services. For microfinance, sustainability can be viewed at several levels and can relate to organizational, managerial, and financial aspects. According to Meyer (2002), sustainability can be measured in two stages, there are operational self-sufficiency and financial self-sufficiency. Operational sustainability refers to the ability of the MFI to cover its operational costs from its operating income. While MFIs are financially self-sufficient when they are able to cover their costs and expenses from their own generating income. Sustainabilty of microfinance is hence becoming more complex and debatable issue from different angles.

In this perspective, the research focuses on the determinants of the performance and the sustainability of conventional and Islamic microfinance institutions. In particular, this study is interested in three types of performance namely, organizational, social, and financial performance. Thus, this paper makes an original contribution in identifying the controllable factors that may be taken into account in the management of MFIs to enable the microfinance sector to continue performing and serving the poor. To the best of the authors' knowledge, unlike several number of studies which focused on only two type of performance namely, social 
and financial performance (Adair \& Berguiga, 2010; Venkata, Kumar, \& Gupta, 2011; Jebli, 2012; Anand \& Sandhya, 2012), this is the first study to examine conjointly three kinds of performance (organizational, social, and financial performance) and the sustainability for a large set of conventional and Islamic microfinance institutions and to determine the major differences between the two types of microfinance.

Section 2 contains a brief comparison between conventional and Islamic microfinance institutions (MFIs). Section 3 exposes the literature review of the different factors determining the performance and the sustainability of the MFIs followed by the hypothesis of this research. Section 4 presents the methodology, including the theoretical models. The 5th section presents the data, the descriptive statistics of the selected variables, and the analysis of the endogenous variables. Section 6 exposes the empirical results, and finally, section 7 concludes the paper.

\section{Conventional and Islamic Microfinance}

According to Ledgerwood (1999), microfinance refers to the provision of financial services to low-income clients. Financial services are generally composed of deposit operations and credits. In addition to financial services, many MFIs provide social services, such as management training, coaching, and others (Boye, Hajdenberg, \& Poursat, 2006). There are several characteristics that distinguish conventional microfinance from Islamic microfinance (Ahmed, 2002). Table 1 represents the converging and diverging elements between conventional and Islamic microfinance. From this table, we note that both conventional and Islamic microfinance institutions mobilize external funds and savings as their financial sources but Zakat (the third of the five basic pillars of Islamic faith) and Waqf (holding and preserving certain physical assets to the long term benefit for the society) are specific sources of funding islamic microfinance (Ahmed, 2002; Ben Abdelkader \& Ben Salem, 2013). Islamic microfinance can also maximize social services by using Zakat to meet the basic needs and increase the participation of the poor (Abdul Rahman, 2007).

Also, conventional microfinance offers interest-based financial services, while Islamic microfinance employs Islamic financing instruments, i.e. Murabaha contract, Mudaraba contract, etc. That Islamic microfinance institutions do not give cash to their clients as loans are not allowed in Islam unless there is no interest or any incremental amount charge on that loan (Abdul Rahman, 2007), i.e. Qard Al-Hasan, which is an interest-free loan, is the only type of loan allowable by the Shariah. Table 2 presents in brief some of the different types of Islamic financial products according to their affiliation principles and their purposes.

Conventional microfinance shows its limits particularly at the very high interest rates (up to $30 \%$ ). Becoming more and more an integral part of the local and international economic and financial system, conventional microfinance faces the same problems of the financial sector in general. These microfinance lenders usually charge the poorest higher rates than the less poorer. In such a situation, the microcredit is not always the solution. Some even argue that disbursing credit to the poor to make financial gains out of the same cannot be the aim of microfinance institutions. Furthermore, the reduced targeting of the poorest and the most vulnerable individuals is considered a limitation of the conventional microfinance sector, which is supposed to include this category of customers excluded from the formal financial and banking sector. However, the Islamic microfinance approach is based on the sharing of risks and fixed repayment benefits and the transparency in a way to protect social welfare and justice. Islamic microfinance utilizes Islamic financial instruments which are based on Profits and Losses Sharing (PLS) schemes rather than loan. Moreover, Islamic microfinance targets not only women but also the family as a whole. 
Table 1

Comparison of Conventional and Islamic Microfinance

\begin{tabular}{|c|c|c|}
\hline Convergence elements & Conventional microfinance & Islamic microfinance \\
\hline Social objective & \multicolumn{2}{|c|}{ Reduce poverty, achieve social equality and financial inclusion } \\
\hline Institutional objective & \multicolumn{2}{|c|}{ Achieve financial independence, to touch high performance and ensure sustainability } \\
\hline Target population & \multicolumn{2}{|l|}{ Excluded from the formal financial system } \\
\hline Institutional risk & \multicolumn{2}{|l|}{ Risk of payment default } \\
\hline Divergence elements & Conventional microfinance & Islamic microfinance \\
\hline Specifications of the target population & Women in particular are more targeted & Targeting the whole family \\
\hline The poorest of the poor & Neglected & $\begin{array}{l}\text { Classified at the beginning of the awareness } \\
\text { list }\end{array}$ \\
\hline Adherence to moral values & $\begin{array}{l}\text { Discontinued due to the use of abusive } \\
\text { interest rates }\end{array}$ & A basic pillar \\
\hline $\begin{array}{l}\text { Type of products offered } \\
\text { (assets/financing method) }\end{array}$ & $\begin{array}{l}\text { Traditional financial products (having } \\
\text { small amounts either for credit or } \\
\text { savings) based on the interest: } \\
\text { microcredit, micro-savings, micro } \\
\text { insurance, and money transfer services. }\end{array}$ & $\begin{array}{l}\text { Islamic financial products specific to the } \\
\text { nature of the target population, based on the } \\
\text { principle of profit and loss sharing: Qard } \\
\text { Al-Hasan, micro-Ijaran, micro-Takaful, } \\
\text { micro-savings (in the form of Islamic } \\
\text { financial contracts), contract Salam, Istisnaa, } \\
\text { Mudaraba, Murabaha, Musharaka ... }\end{array}$ \\
\hline Liabilities & External funds + deposits & $\begin{array}{l}\text { External funds + Islamic deposits (Wadiah } \\
\text { form of Mudaraba investment) + Islamic } \\
\text { charitable sources (Zakat, Waqf) }\end{array}$ \\
\hline Funding method & Grant credits & $\begin{array}{l}\text { Finance small and micro projects with direct } \\
\text { investment through Islamic contracts }+ \text { grant } \\
\text { loans without interest (al Qard Hassan al) }\end{array}$ \\
\hline Transferring funds & Transfer of money & Transfer of goods \\
\hline $\begin{array}{l}\text { Withheld at the conclusion of the } \\
\text { contract }\end{array}$ & $\begin{array}{l}\text { Part of the funds deducted as launching } \\
\text { of the contract }\end{array}$ & No deduction \\
\hline Encouraging employees to work & Monetary & Monetary and religious \\
\hline Treatment with defects & Group centre of pressure and threat & $\begin{array}{l}\text { Group centre, } \\
\text { common warranty and Islamic ethics }\end{array}$ \\
\hline Social development program & $\begin{array}{l}\text { Secular social behavioral and } \\
\text { ethical development }\end{array}$ & $\begin{array}{l}\text { Religious } \\
\text { (including behavior, ethics, and social) }\end{array}$ \\
\hline
\end{tabular}

Table 2

\section{Different Types of Islamic Financial Products}

\begin{tabular}{|l|l|}
\hline Affiliation principle/purpose & Type of contracts \\
\hline $\begin{array}{l}\text { Sale-based principle contracts/Funding } \\
\text { contracts }\end{array}$ & $\begin{array}{l}\text { Murabaha Contract: it is a contract of sale, where an intermediary buys an asset the cost } \\
\text { and profit margin (markup) are made known and agreed upon all parties involved at the } \\
\text { compmencement of the contract. It is not an interest-bearing loan, yet similar in } \\
\text { structure to a rent to own arrangement, the intermediary retains ownership of the asset } \\
\text { until the loan is paid. } \\
\text { Salam Contracts: it is a sale whereby the seller undertakes to supply some specific } \\
\text { goods to the buyer at a future date in exchange for an advanced payment of the price in full. } \\
\text { Istisna' Contract: it is a construction contract with a progressive funding process, where } \\
\text { a party undertakes to produce and sell a specific product to be made according to agreed } \\
\text { upon specifications at a pre-determined price. }\end{array}$ \\
\hline $\begin{array}{l}\text { Pusharaka Contracts: contract between two or more partners sharing both profits and } \\
\text { losses. Instead of charging interest as a creditor, the financier will achieve a return in the } \\
\text { form of a proportion of the actual profits earned, according to a predetermined ratio. } \\
\text { contracts/Investment contracts }\end{array}$ & $\begin{array}{l}\text { However, unlike a traditional creditor, the financier will also share in any losses. } \\
\text { Mudharaba Contracts: it is a partnership in which one partie provides the capital and the } \\
\text { other provides the labour or the skill. The capital provider is known as Rab Al-Mal } \\
\text { while the counterpart is known as the Mudarib. It is a trust contract, the mudarib is not } \\
\text { liable for losses except in case of breach of the requirements of trust. }\end{array}$ \\
\hline
\end{tabular}


Table 2 continued

\begin{tabular}{|l|l|}
\hline Affiliation principle/purpose & Type of contracts \\
\hline Lease-based principle contracts & $\begin{array}{l}\text { jjara Contracts: it is a medium-term financing means and it can operate on the operating } \\
\text { or the financial lease mechanism. It is similal to a conventional lease in which the owner } \\
\text { rents or leases his property or goods to a lessee for a specified number of periods for a } \\
\text { fee. The difference between the two is that in an operating lease, the asset is returned to } \\
\text { the owner at the end of the lease term whereas in a financial lease, the asset is } \\
\text { transferred to the lessee at the end of the lease term. }\end{array}$ \\
\hline Benevolent-loan principle contracts & $\begin{array}{l}\text { Qard Al-Hasan: it is an interest free loan, the only type of loan that is recongnized in the } \\
\text { Islamic law, where the borrower only repays the principal amount and the financial } \\
\text { institutions are prohibited from charging profit. }\end{array}$ \\
\hline Saving contracts & $\begin{array}{l}\text { Wadiah Contract: it is a safekeeping conhtract based on the principal of trust. Modern } \\
\text { Islamic banks practice Wadiah in their savings and current account. }\end{array}$ \\
\hline
\end{tabular}

The financial and economic crisis of 2008 revealed other challenges that conventional microfinance faces. Barlet (2009) showed that these new challenges or risks can be divided into three "groups" of vulnerability for MFIs: the worsening of the economic conditions, the threats associated with the funding and liquidity, and the potential damage of the microfinance reputation.

However, Islamic microfinance has not been able to achieve a successful financial model which allows it to reach a large number of clients on a cost-effective basis. Islamic microfinance institutions are still unable to convince Islamic banks to invest in their portfolio because they are perceived as a very risky sector. Moreover, the Islamic microfinance sector suffers from a lack of qualified personnel in the field. It is a disadvantage that it can affect the quality of services and the credibility to the Sharia compliance. A problem intensified by the unavailability or the lack of the risk management tools is specific to the Islamic industry. These institutions have an urgent need for the introduction of risk management techniques consistent with the standards and specificities of its business.

\section{Literature Review and Hypotheses}

Although microfinance institutions are "non-profit" institutions, with a primarily mission to reach the poor excluded clients, non financial parameters are always employed to assess their performance. The focus on social performance appears to be at the expense of the financial health of MFIs. However, the procedures and the methodologies to assess the sustainability are scarce.

According to Ledgerwood (1999), the performance indicators are usually in the form of reports, which is a comparison of a set of financial data with another. The concepts of sustainability and performance are explained differently over time with various assumptions and determinants (Ayayi \& Sene, 2010; Hartarska \& Nadolny, 2007; Mersland \& Strom, 2009; Ahlin, Lin, \& Maio, 2010; Bourguiga \& Adair, 2010; Allaire, Ashta, Attuel-Mendes, \& Krishnaswamy, 2009; Jebli, 2012; Agarwal \& Sinha, 2010; Ejigu, 2009; Regassa \& Negash, 2014). This study focuses on identifying factors that affect the organizational performance, social performance, financial performance, and sustainability of microfinance institutions.

\section{Factors Explaining Organizational Performance}

Organizational performance of MFIs is based primarily on the capacity of its human resources. This implies a clear division of functions (management, operations, audit, human resources...) and codified procedures to be rigorously enforced. Boye et al. (2006) indicated that a structure is viable at the organizational level if it has the structures, processes, and human resources to operate effectively in line with the strategy that is attached to it. Such a structuring effort is a key issue of the sustainability of MFIs. The ratio of Operating 
Expenses and the ratio of Personnel Expenses represent the efficiency of the credit operation indicators (Ledgerwood, 1999), also called management indicators (Séne, 2010). Organizational effectiveness of microfinance institution measures their ability to overcome the costs of their operations. Based on the studies already mentioned, the present study supposes the following hypothesis:

H1: There is a negative relationship between expense ratios and organizational performance.

\section{Factors Explaining Social Performance}

Social performance reflects a measure of the MFI's intentions to have a social impact and proper integration in its environment (Boye et al., 2006). It clarifies the objective of the struggle against poverty for a microfinance institution. With the absence of harmonized and standard indicators worldwide, proxies are employed, which essentially measure the social impact in terms of degree or scope (Adair \& Berguiga, 2010).

"The number of customers" is used as a measure of the scale of outreach of an MFI services in several studies (Mersland \& Strom, 2009; Luzzi \& Weber, 2006). In addition, Hartarska and Nadolnyak (2007) and Hartarska (2005) used "the logarithm of the number of active borrowers".

Mersland and Strom (2009); Ayayi and Sene (2010); De Crombrugghe, Tenikue, and Sureda (2008); and Hartarska (2005) used "the average loan balance per borrower" in order to evaluate the depth of outreach. The lower the average is, the more the MFI is targeting the poorest. Other researchers used "the percentage of female borrowers" among the MFI clients to measure the depth of outreach (Cull, Demirguç-Kunt, \& Morduch, 2007; Ayayi \& Sene, 2010; Luzzi \& Weber, 2006).

Several studies showed that the scope of an MFI refers to the number of served clients. It is clear that the more clients a microfinance institution has, the more it can benefit from economies of scale and thus cover its fixed costs and make a profit (Hartarska, 2005; Luzzi \& Weber, 2006; Hartarska \& Nadolnyak, 2007; Mersland \& Strom, 2009; Adair \& Berguiga, 2010; Jebli, 2012). According to the studies already mentioned, the second hypothesis is formed as follows:

$\mathrm{H} 2$ : The greater the scope of services of a microfinance institution, the greater its social performance improves.

\section{Factors Explaining the Financial Performance}

Financial performance is the ability of an MFI to cover the set of its expenses by its income and finance its growth (El Kharti, 2013). Financial performance is mainly measured by financial and operational self-sufficiency, as well as the achievement of profitability maximizing the efficiency and productivity i.e. "return on equity (ROE)" and "return on asset (ROA)" (Sene, 2010; Adair \& Berguiga, 2010). The ROE is particularly important for private entities with shareholders seeking profits. However, given that most of the MFIs are nonprofit, this ratio is rather used as an alternative indicator to measure the commercial viability (Ledgerwood, 1999). Unlike the ROE, the ROA measures the profitability regardless of the underlying funding structure of the institution, and enables to compare profit and nonprofit MFIs.

To determine the factors that have a relationship with the financial performance, Ayayi and Sene (2010) analyzed a sample of 217 MFIs in different legal forms, originating from 101 countries in different parts of the globe. Their study covers the period between 1998 and 2006. The authors used financial self-sufficiency as an independent variable in their model. The results showed that the factors that have a positive impact on the financial performance of MFIs are, in order of importance, the quality of the loan portfolio measured by portfolio at risk followed by the interest rate applied and the quality of management (as measured by the ratio of operating expenses and the ratio of personnel expenses) and finally, the scale of activities of MFIs and their 
ages: these two factors are statistically significant but have less influence on the financial performance of MFIs. Jebli (2012) analyzed a sample of 10 Moroccan micro-credit associations (MCA), over the period between 2003 and 2010. In this study, the author used the operational self-sufficiency and profitability of assets to determine the factors affecting the financial performance. The results show that the factors that have a positive impact on the financial performance of the MCA are the scale of outreach measured by the number of active borrowers, the level of debt indicator of the financing structure, measured by the ratio of debt to equity and the portfolio quality measured by portfolio at risk.

The financial performance is measured by three accounting ratios commonly used for this purpose: the return on assets (ROA), return on equity (ROE), and cash flow ratio (Ledgerwood, 1999; Ayayi \& Sene, 2010; Bruett, 2005; Hartarska, 2005; Cull et al., 2007; Mersland \& Strom, 2008; 2009).

H3: A good control of portfolio quality and a balanced financial management improve the financial performance.

\section{Measurement of the Sustainability of MFIs}

The sustainability of a microfinance institution can be defined as the ability to generate sufficient revenues to cover up all the operational and financial expenses (Epstein, Buhovac, \& Yuthas, 2010). Ducroux (2001) showed that a sustainable institution is an institution that has gained its independence on the organizational, technical, financial, institutional, and social level.

The combination of three types of performance i.e. organizational, social, and financial performance generates the sustainability of microfinance institutions (Boye et al., 2006). Many empirical studies used two levels of self-sufficiency (operational and financial) as determinants of the sustainability of MFIs. The first aspect of the financial, operational self-sufficiency was used by Hudon and Niyongabo (2009) as a determinant of sustainability for 83 microfinance institutions rated by PlaNet rating for the period between 2002 and 2005. The results of the study showed that the organizational structure or the experience of the MFIs has no role in the sustainability of the studied MFIs.

Several previous researchers (Tucker, 2001; Stephens, 2005; Schreiner, 2002) attempted to assess the indicators that affect sustainability in its financial aspect. Tucker (2001) found that both staff productivity and organizational structure of the MFI (such as NGOs, for-profit organizations, and cooperatives) have a positive impact on the sustainability of MFIs. Stephens (2005) identified the number of years in practice as factors explaining the sustainability of MFIs showed some differences according to the geographical location. Results indicated that the number of borrowers and the ratio of the operating expenses were positively related to the sustainability of the studied MFIs. Schreiner (2002) found that the degree of the scope has a negative impact on the financial self-sufficiency as an indicator of the sustainability of the MFIs studied. Under this perspective, the fourth hypothesis is formulated as follows:

H4: The microfinance institution must attain organizational, social, and financial performance to ensure its sustainability and continue to serve its clients.

\section{Methodology and Model Specification}

To assess the performance and sustainability of MFIs, the study resorted to several variables. Unlike previous studies, this study gauges the determinants of each different type of performance of conventional and Islamic MFIs separately. Then on another stage, it analyzes the impact of this performance on sustainability. 


\section{Organizational Performance}

To study the organizational performance of conventional and Islamic MFIs, this empirical research estimated the following model:

Model 1:

$$
\text { ABPCOijt }=\alpha 0+\alpha 1 \text { OERijt }+\alpha 2 \text { PERijt }+\varepsilon t
$$

with:

$i=1, \ldots, 382$ (conventional and Islamic MFIs);

$j=1, \ldots, 17$ (years of 1996-2012);

$t=1,0$ (" 1 " if the MFI is Islamic, " 0 " if the MFI is conventional);

$A B P C O i j t=$ the number of active borrowers per loan officer of the observed MFI $i$ at time $t$;

OERijt $=$ operating expenses ratio of the observed MFI $i$ at time $t$;

PERijt $=$ personnel expenses ratio of the observed MFI $i$ at time $t$.

\section{Social Performance}

The model used to estimate the determinants of the social performance of conventional and Islamic MFIs is written as follows:

Model 2:

with:

$$
A L B P B i j t=\beta 0+\beta 1 N A B i j t+\beta 2 P F B i j t+\beta 3 \text { Lnassetijt }+\beta 4 \text { Ageijt }+\varepsilon t
$$

$A L B P B i j t=$ the average loan balance per borrower of the MFI $i$ observed at time $t$;

$N A B i j t=$ the number of active borrowers of the MFI $i$ observed at time $t$;

PFBijt $=$ the percentage of female borrowers of MFIs observed $i$ at time $t$;

Lnasset $=$ a control variable retained as an indicator of the size of the IMF $i$ observed at time $t$;

$A g e=$ a control variable represents the age of the MFI $i$ observed at date $t$.

\section{Financial Performance}

In order to analyze the determinants of financial performance of all the MFIs, the following regression is employed:

Model 3:

with:

$$
\text { ROAijt }=\gamma 0+\gamma 1 \text { PaRijt }+\gamma 2 \text { Rcijt }+\gamma 3 \text { Deijt }+\gamma 4 \text { Caijt }+\gamma 5 \text { BPSMijt }+\varepsilon t
$$

ROAijt $=$ return on assets of the MFI observed $i$ at time $t$;

PaRijt $=$ Portfolio at Risk of MFIs observed $i$ at time $t$;

$R c i j t=$ the risk coverage for the MFI $i$ observed at time $t$;

Deijt $=$ the debt to equity ratio of The IMF $i$ observed at date $t$;

Caijt $=$ the capital/total asset ratio of the IMF $i$ observed at time $t$;

$B P S M i j t=$ the control variable is: borrowers per staff member of IMF $i$ observed at date $t$.

\section{Sustainability}

As shown below the model used to estimate the durability of conventional and Islamic MFIs:

Model 4:

with:

$$
\text { OSSijt }=\delta 0+\delta 1 A B P L O i j t+\beta 2 A L B P B i j t+\delta 3 R O A i j t+\varepsilon t
$$

$O S S i j t=$ operational self-sufficiency of IMF $i$ observed at time $t$. 


\section{Data and Variable Analysis}

\section{Data and Descriptive Statistics}

The present study uses a panel dataset of 333 conventional MFIs located in six different regions and 49 Islamic MFIs in five different regions, from January 1996 to December 2012 (Table 2). The data were extracted from the Microfinance Information Exchange database (MIX-www.mixmarket.org).

Table 3

Geographical Distribution of Conventional and Islamic MFIs Sample

\begin{tabular}{|c|c|c|c|c|c|c|c|c|c|c|c|c|c|c|c|c|}
\hline \multirow{3}{*}{$\begin{array}{l}\text { Africa } \\
\text { Countries }\end{array}$} & \multirow{2}{*}{\multicolumn{2}{|c|}{$\begin{array}{c}\text { Number of } \\
\text { MFIs }\end{array}$}} & \multicolumn{3}{|c|}{ East Asia and the Pacific } & \multicolumn{3}{|c|}{$\begin{array}{c}\text { Eastern Europe and Central } \\
\text { Asia }\end{array}$} & \multicolumn{2}{|c|}{$\begin{array}{c}\text { Latin American and the } \\
\text { Caribbean }\end{array}$} & \multicolumn{3}{|c|}{$\begin{array}{l}\text { Middle East and North } \\
\text { Africa }\end{array}$} & \multicolumn{3}{|c|}{ South Asia } \\
\hline & & & \multirow[t]{2}{*}{ - Countries } & \multicolumn{2}{|c|}{$\begin{array}{l}\text { Number of } \\
\text { MFIs }\end{array}$} & \multirow{2}{*}{ - Countries } & \multicolumn{2}{|c|}{$\begin{array}{c}\text { Number of } \\
\text { MFIs }\end{array}$} & \multirow[t]{2}{*}{ Countries } & \multirow{2}{*}{$\begin{array}{c}\text { Number of } \\
\text { MFIs }\end{array}$} & \multirow[t]{2}{*}{ _ Countries } & \multicolumn{2}{|c|}{$\begin{array}{c}\text { Number of } \\
\text { MFIs }\end{array}$} & \multirow[t]{2}{*}{ Countries } & \multicolumn{2}{|c|}{$\begin{array}{c}\text { Number of } \\
\text { MFIs }\end{array}$} \\
\hline & CMFIs & IMFIs & & CMFIs & IMFIs & & CMFIs & IMFIs & & & & CMFIs & IMFIs & & CMFIs & IMFIs \\
\hline South Sudan & & 1 & Malaysia & & 1 & Uzerbekstan & & 1 & Argentina & 7 & Syria & & 1 & Afghanistan & 3 & 2 \\
\hline Benin & 3 & & Cambodia & 8 & & Albania & 7 & & Belize & 14 & Iraq & & 4 & Bangladesh & 12 & 1 \\
\hline Burkina Faso & 4 & & China & 2 & 1 & Armenia & 13 & & Bolivia & 11 & Egypt & 1 & 2 & India & 12 & 1 \\
\hline Burundi & 2 & & East Timor & 1 & & Azerbaïdjan & 13 & & Brazil & 11 & Jordan & 1 & 2 & Nepal & 7 & \\
\hline Cameroun & 6 & & Fiji & 1 & & Bosnia and $\mathrm{H}$. & 2 & & Chile & 4 & Lebanon & 2 & & Pakistan & 9 & 13 \\
\hline Chad & 1 & & Indonesia & 2 & 8 & Bulgaria & 7 & & Colombia & 8 & Morocco & 7 & & Sir Lanka & 2 & \\
\hline C R D & 2 & & Laos & 3 & & Croatia & 1 & & Costa Rica & 4 & Palestine & 1 & 2 & Bhutan & 1 & \\
\hline Ivory Coast & 1 & & P.N.Guinée & 7 & & Georgia & 5 & & Dominicain R. & 3 & Tunisia & 1 & & & & \\
\hline Ethiopia & 3 & & Philippines & 7 & & Kazakhstan & 1 & & Ecuador & 3 & Yemen & 1 & 7 & & & \\
\hline Gambia & 1 & & Samoa & 1 & & Kosovo & 4 & 2 & Elsalvador & 4 & & & & & & \\
\hline Ghana & 2 & & Thaïland & 1 & & Kyrgyzstan & 9 & 1 & Guatemala & 4 & & & & & & \\
\hline Guinea & 3 & & Tonga & 2 & & Macedonia & 3 & & Haïti & 3 & & & & & & \\
\hline Kenya & 4 & & Vietnam & 2 & & Moldove & 2 & & Honduras & 4 & & & & & & \\
\hline Liberia & 1 & & & & & Mongolia & 2 & & Jamaïque & 1 & & & & & & \\
\hline Madagascar & 4 & & & & & Montenegro & 2 & & Mexico & 10 & & & & & & \\
\hline Mali & 3 & & & & & Romania & 1 & & Nicaragua & 5 & & & & & & \\
\hline Mozambique & 2 & & & & & Russia & 3 & & Panama & 3 & & & & & & \\
\hline Nambia & 1 & & & & & Serbia & 4 & & Paraguay & 5 & & & & & & \\
\hline Niger & 3 & & & & & Tadjikistan & 2 & & Peru & 9 & & & & & & \\
\hline Nigeria & 1 & & & & & Turkey & 2 & & $\mathrm{~T}$. and $\mathrm{T}$. & 1 & & & & & & \\
\hline Rawanda & 1 & & & & & Ukraine & 8 & & Venezuela & 1 & & & & & & \\
\hline Senegal & 2 & & & & & & & & & & & & & & & \\
\hline \multicolumn{17}{|c|}{ South Soudan 1} \\
\hline Swaziland & 1 & & & & & & & & & & & & & & & \\
\hline Tanzanie & 1 & & & & & & & & & & & & & & & \\
\hline Togo & 1 & & & & & & & & & & & & & & & \\
\hline Zimbabwe & 1 & & & & & & & & & & & & & & & \\
\hline Uganda & 3 & & & & & & & & & & & & & & & \\
\hline
\end{tabular}

Descriptive statistics for Conventional and Islamic MFIs are presented in Table 3. Islamic MFIs are more recent and younger ( $\max 23$ years) compared to the conventional MFI (max 65 years), which could be considered as one of the reasons that conventional MFIs are reaching more clients (CMFI: max: 6,700,000 vs. IMFI: max: 440,461). On the contrary, IMFIs touch a 100\% of female, the kind of borrowers who are considered as the poorest of the poor suggesting that Islamic MFIs are better at promoting women empowerment. By observing the financial statements, it can be clearly seen that both types of MFIs show in different proportions, an operational self sufficiency (CMFI: max: 18.4365 vs. IMFI: max: 4.3434). This could be explained by the registered results of their Return on Asset (CMFI: max: 5.84 vs. IMFI: max: 0.8985). As well as by their ability of risk covering (CMFI: max: 1,958.55 vs. IMFS: max: 243.0927). Furthermore, in the Table 4, the average of 
the debt ratio of Conventional MFIs is largely superior to the same ratio of Islamic MFIs. This implies that debt is one of the external sources that conventional MFIs use to accomplish their mission.

Table 4

Descriptive Statistics of Conventional and Islamic MFIs Variables

\begin{tabular}{|c|c|c|c|c|c|c|c|c|c|c|}
\hline \multicolumn{6}{|c|}{ Panel A: Conventional MFIs } & \multicolumn{5}{|c|}{ Panel B: Islamic MFIs } \\
\hline Variables & Observations & Mean & $\begin{array}{l}\text { Std. } \\
\text { deviation }\end{array}$ & Min & Max & Observations & Mean & $\begin{array}{l}\text { Std. } \\
\text { deviation }\end{array}$ & Min & Max \\
\hline Age & 5661 & 10.8321 & 9.266481 & 0 & 65 & 833 & 3.831933 & 5.422583 & 0 & 23 \\
\hline$C A$ & 5661 & 0.2601517 & 0.3149229 & -1.5695 & 3.8777 & 833 & 0.2047425 & 0.337604 & -0.5421 & 1 \\
\hline$N A B$ & 5661 & $68,669.66$ & 9.266481 & 0 & $6,710,000$ & 833 & $11,627.34$ & 39654.37 & 0 & 440,461 \\
\hline$P F B$ & 5661 & 0.4106789 & 0.3149229 & 0 & 99.56 & 833 & 0.2151941 & 0.3415474 & 0 & 1 \\
\hline$B P S M$ & 5661 & 81.65 & 1.824153 & 0 & 884 & 833 & 46.58463 & 72.87417 & 0 & 349 \\
\hline$R O A$ & 5660 & 0.0056517 & 98.14734 & -13.91 & 5.84 & 833 & -0.0022905 & 0.0760938 & -0.8085 & 0.8985 \\
\hline OSS & 5660 & 0.7414309 & 0.9506945 & -4.4525 & 18.4365 & 833 & 0.442308 & 0.6324504 & -0.0981 & 4.3434 \\
\hline$O E R$ & 5661 & 0.1409663 & 0.794335 & -1.3329 & 4.3266 & 833 & 0.098155 & 0.3132824 & 0 & 6.33 \\
\hline PER & 5661 & 0.0581783 & 0.2546391 & 0 & 3.17 & 833 & 0.0477279 & 0.1094705 & 0 & 1.0911 \\
\hline PaR & 5661 & $1,043.235$ & 0.1163211 & 0 & $5,904,301$ & 833 & 0.0251461 & 0.0732515 & 0 & 0.632 \\
\hline$R C$ & 5661 & 2.293591 & $78,473.3$ & -3.8349 & $1,958.55$ & 833 & 1.318275 & 14.70779 & 0 & 243.0927 \\
\hline Assets & 5661 & $4.30^{\mathrm{e}}+07$ & 35.35536 & 0 & $5.60^{\mathrm{e}}+09$ & 833 & $9,215,101$ & $3.51^{\mathrm{e}} 07$ & 0 & $4.61^{\mathrm{e}}+08$ \\
\hline Lnasset & 5661 & 11.08245 & $2.31^{\mathrm{e}}+08$ & 0 & 27.96309 & 833 & 6.749979 & 7.60592 & 0 & 19.94898 \\
\hline$D E$ & 5661 & 7.802808 & 7.40011 & $-2,478.24$ & 24,137 & 833 & 0.7439136 & 39.93604 & -878.62 & 611.82 \\
\hline$A L B P B$ & 5661 & $114,043.5$ & $2,671,947$ & 0 & $1.03^{\mathrm{e}}+08$ & 833 & 282.8151 & 737.4535 & 0 & 7573 \\
\hline$A B P L O$ & 5660 & 120.851 & 200.297 & 0 & 2365 & 833 & 75.28571 & 137.9573 & 0 & 827 \\
\hline
\end{tabular}

\section{Analysis of Endogenous Selected Variables}

Figures 1-4 expose the evolution of the dependent variables of each estimated models, respectively the number growth of active borrowers per credit officer of conventional and Islamic MFIs (Figure 1), the average loan balance for all the studied MFIs (Figure 2), the ROA ratio (Figure 3), and the annual average operational self-sufficiency of conventional and Islamic MFIs (Figure 4) over the period studied (1996-2012).

The following four figures are the evolution of the performance and persistence variables of Islamic and conventional MFIs (1996-2012).

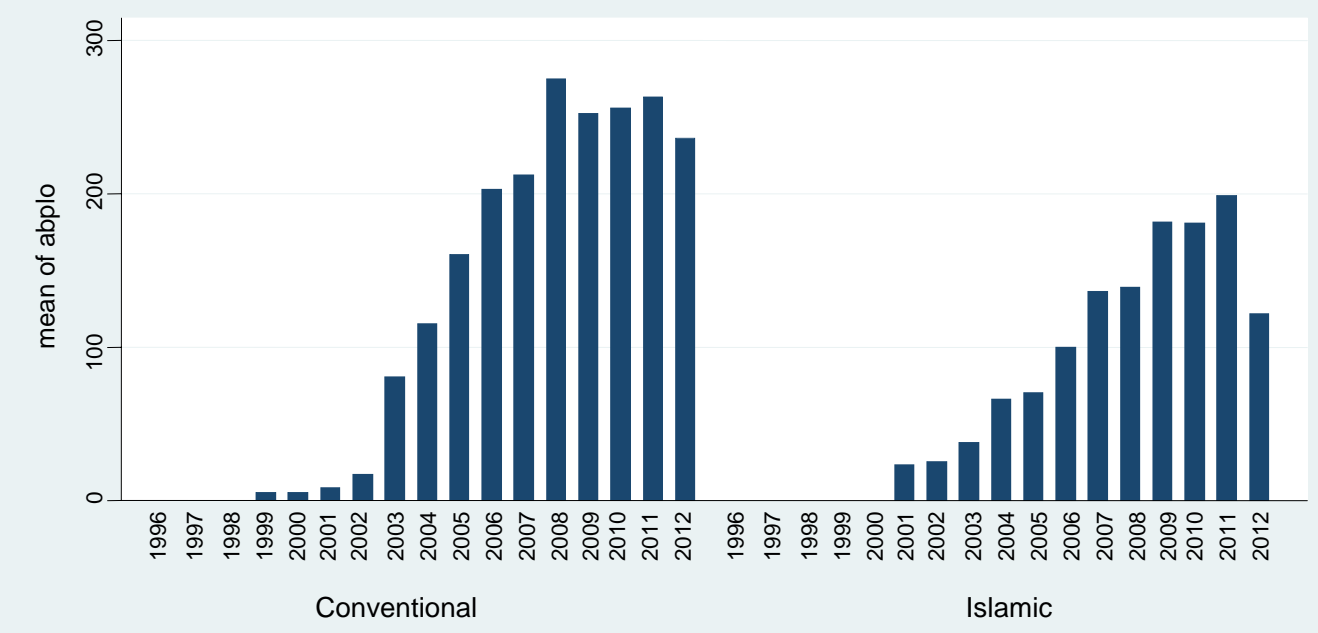

Figure 1. The number of active borrowers per credit officer. 
Figure 1 shows an upward trend of the productivity ratio before, during, and after global financial crisis of 2008 for the Islamic MFIs. Therefore, productivity is high within these institutions. Moreover, it can be noticed that this ratio increased in 2008 and then decreased in 2009 for conventional MFIs. However, as can be seen that the productivity ratio remained stable during the first two years of the crisis (2007-2008), and then rose in 2009 for the Islamic MFIs. The decrease of this ratio may be due to the decrease of the number of active borrowers.

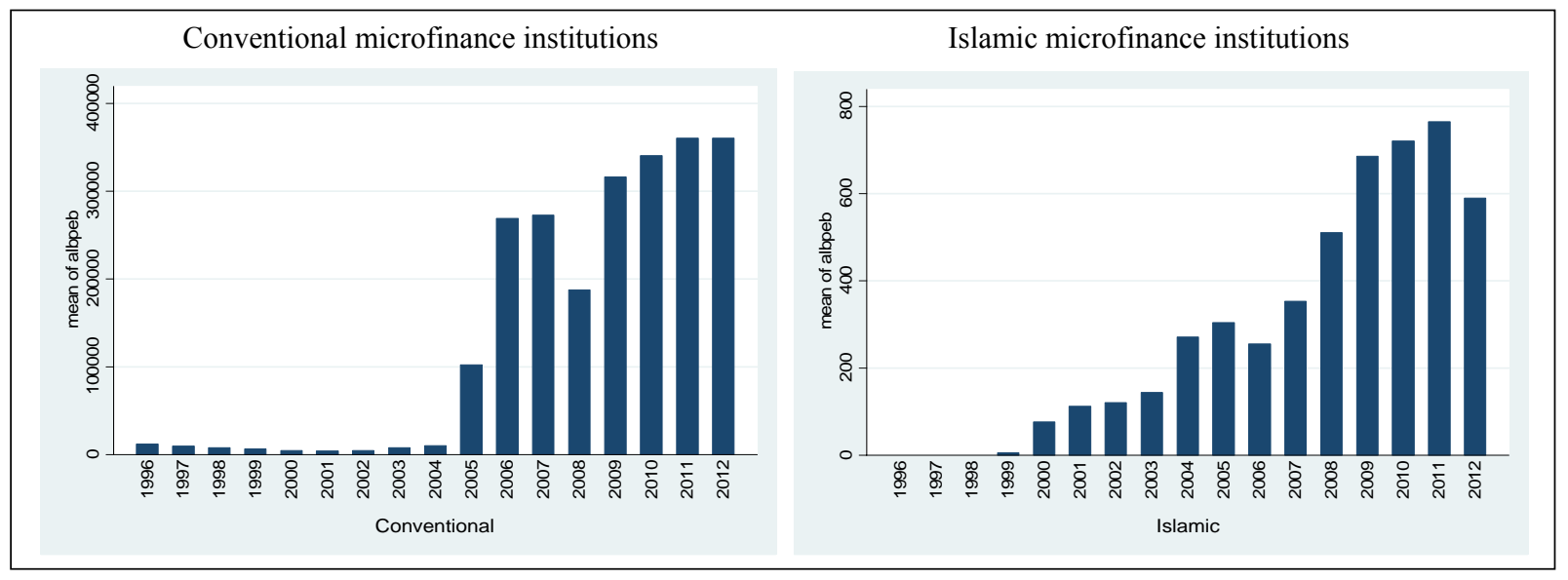

Figure 2. The average loan (ALBPB).

By observing Figure 2, it can be noticed that the average loan of conventional MFIs has increased since 2005 suggesting that they have gone from an industry that target the poor and the poorest during their very first years of existing, then they directed their attention to financing medium and small projects whereas the poorest are neglected. Contrariwise, the Islamic MFIs are targeting the poor, due to the low average balance of loans that they offer to their customers. Even the upward or downward evolution does not seem stable. The average balance of loans of Islamic MFI does not exceed the minimum that conventional MFIs offer.

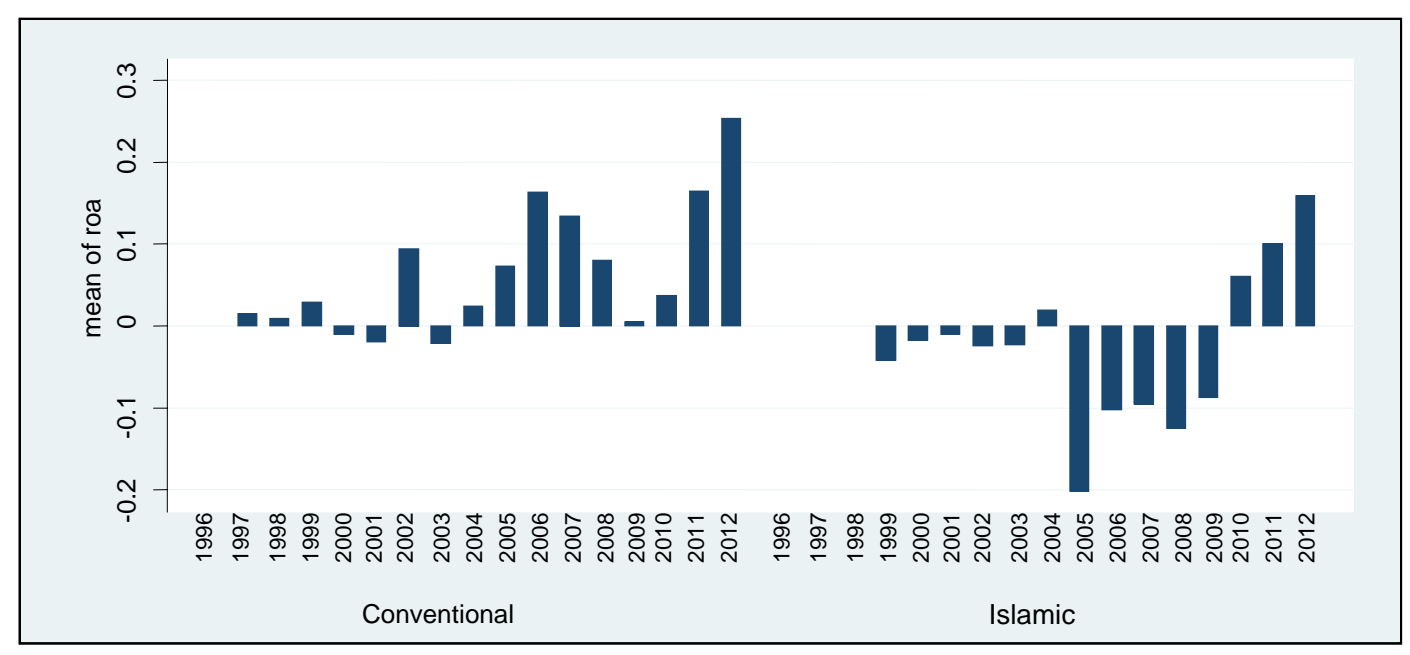

Figure 3. The ROA ratio.

Figure 3 shows the low profitability of assets of Islamic MFIs. However, the heterogeneity in case of conventional MFIs can be observed at the beginning of the study period. Even if this deficit has been observed 
since 2004, it remains fairly weak and unstable. Moreover, it may as well notice the influence of the global crisis of 2008, through the declined profitability of assets for CMFIs in 2009. The same is also noticed in the case of IMFIs. The return on assets of the two types of microfinance institutions, ended with a rising trend over the last three years of the study period.

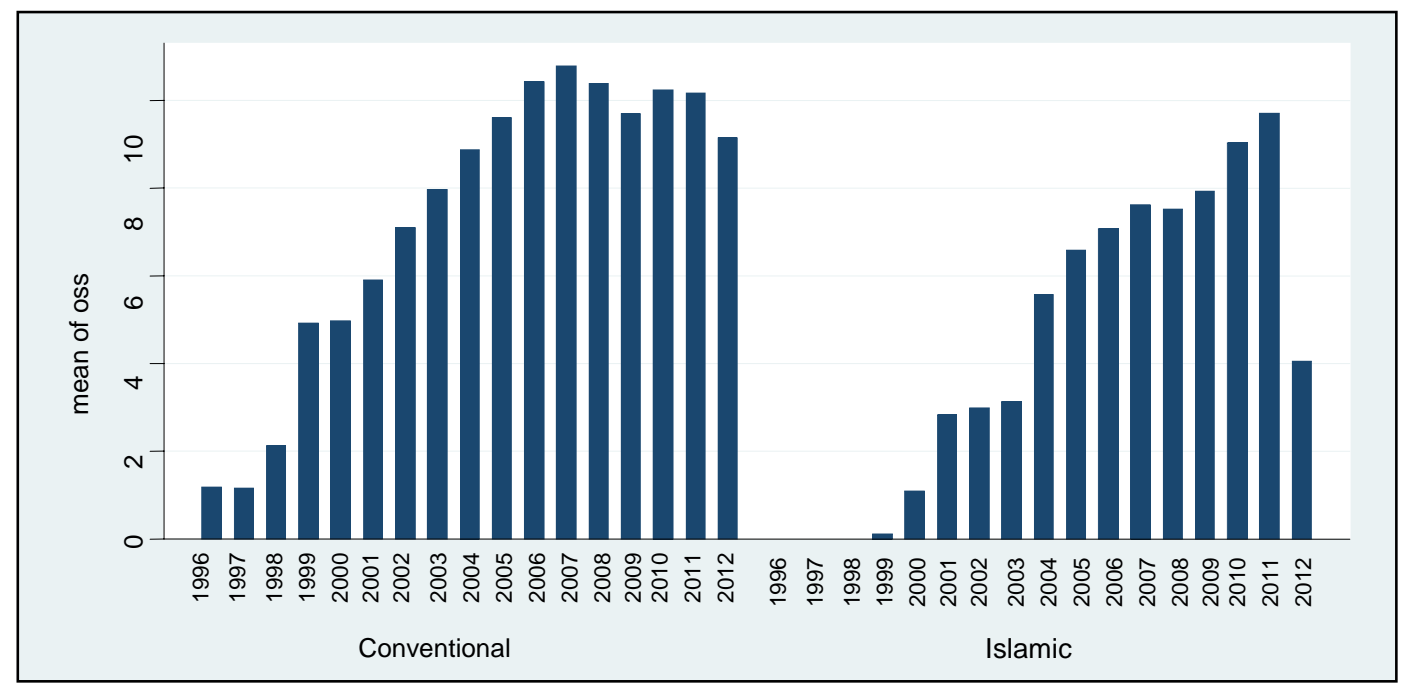

Figure 4. The annual operational self-sufficiency.

Figure 4 notes that this annual average was over $100 \%$ in the case of conventional MFIs throughout the study period except for 2001 and 2003. It should be recalled that if an MFI has an operational self sufficiency greater than $100 \%$, thus, this MFI reaches its financial viability. It therefore has the ability to continue to operate its business without needing to be subsidized. The average of the operational self sufficiency variable on the studied period is equal to $122.04 \%$ (Table 3). The situation is different in the case of Islamic MFIs but this can be explained by the fact that IMFIs are still recent.

\section{Empirical Results}

This section presents the estimation results of the determinants of the three types of performance already presented above, and the sensibility of sustainability to each one of them for conventional and Islamic MFIs.

\section{Determinants of Organizational Performance}

Table 5 presents the regression results of the organizational performance model. Panel "A" concerns the conventional MFIs and the panel "B" the Islamic MFIs.

Table 5

Estimation Results of Organizational Performance (ABPLO)

\begin{tabular}{|c|c|c|c|c|}
\hline Variable & Coefficient & Std. error & $t$-statistic & Prob. \\
\hline \multicolumn{5}{|c|}{ Panel A: Conventional MFIs } \\
\hline OER & -6.99706 & 13.81899 & -2.68 & 0.007 \\
\hline PER & 5.11067 & 30.25178 & 16.89 & 0.0000 \\
\hline \multicolumn{5}{|c|}{ Panel B: Islamic MFIs } \\
\hline OER & 6.12004 & 17.54001 & 0.35 & 0.148 \\
\hline PER & 9.160623 & 50.19595 & 9.25 & 0.0000 \\
\hline
\end{tabular}


The ratio of operating expenses (OER) measures the costs necessary for the institution to provide its credit services. Efficiency is affected by the increase or decrease of the operating costs compared to the average loan portfolio. The lower this ratio is, the more efficiency improves. A negative coefficient is showed for conventional MFI, which is equal to -6.99706 , the more that ratio increases, the more the organizational performance is weakened and and vice versa. Or in the case of Islamic MFIs, the OER ratio does not affect organizational performance. The ratio of personnel expenses is statistically significant as an explanatory variable of organizational performance measured by the number of active borrowers per loan officer (ABPLO) for both types of MFIs. Normlly, a negative effect is expected, in other words, a lower personnel expense ratio indicates a greator profit for the institution. Yet, the regression results showed a positive effect of these type of expenses. It indicates that personnel expenses were averagely stable during the period of this study for both type of microfinance institutions, thus posively affected their organizational performane.

\section{Determinants of Social Performance}

Table 6 reports the estimation results of the factors explaining social performance. The panel "A" concerns conventional MFIs and the panel "B" concerns Islamic MFIs.

Table 6

Determinants of Social Performance (ALBPB)

\begin{tabular}{|c|c|c|c|c|}
\hline Variable & Coefficient & Std. error & $t$-statistic & Prob. \\
\hline \multicolumn{5}{|c|}{ Panel A: Conventional MFIs } \\
\hline NAB & $1,366.21$ & $11,186.681$ & 2.03 & 0.043 \\
\hline PFB & 0.0076801 & 0.136354 & 0.06 & 0.955 \\
\hline Age & 782.81 & 553.329 & 3.80 & 0.000 \\
\hline Lnasset & 390.21 & 797.78 & 0.63 & 0.526 \\
\hline \multicolumn{5}{|c|}{ Panel B: Islamic MFIs } \\
\hline NAB & 560.9376 & 78.26964 & 7.17 & 0.000 \\
\hline PFB & 0.0019342 & 0.0007354 & 2.63 & 0.009 \\
\hline Age & 53.4302 & 4.780244 & 11.18 & 0.000 \\
\hline Lnasset & 43.42121 & 2.884129 & 15.06 & 0.000 \\
\hline
\end{tabular}

According to the estimation results, the NAB of conventional MFIs negatively influences their social performance as measured by the ALBPB (the average loan balance per borrower). This means that the more conventional MFIs affect a large number of borrowers, the lower its average balance per loan. The variables age and size (Lnasset) positively influence the social performance of conventional MFIs, with coefficients respectively equal to 12.198 (Prob. 0.0000) and 6.5888 (Prob. 0.090). Thus, the activities of conventional MFIs record low average loan balances, when they are ancient, big in economic size, and reach high percentages of women who are considered the most vulnerable.

With statistically significant positive coefficients the explanatory variables NAB and PFB equal to 53.4302 (Prob. 0.0000) and 43.42121 (Prob. 0.001) respectively, affected the average loan balance of Islamic MFIs. The more Islamic institutions affect a large number of borrowers and specifically more women, the more they provide financing on average amounts.

\section{Determinants of Financial Performance}

Table 7 presents the estimation results of the financial performance model. Panel "A" concerns conventional MFIs and " $\mathrm{B}$ " concerns Islamic MFIs. 
Table 7

Estimation Results of Financial Performance (ROA)

\begin{tabular}{|c|c|c|c|c|}
\hline Variable & Coefficient & Std. error & $t$-statistic & Prob. \\
\hline \multicolumn{5}{|c|}{ Panel A: Conventional MFIs } \\
\hline $\mathrm{CA}$ & 0.0072416 & 0.0046202 & 0.94 & 0.292 \\
\hline $\mathrm{PaR}$ & 0.0914967 & 0.0173013 & 1.57 & 0.000 \\
\hline $\mathrm{RC}$ & 0.0091052 & 0.0003574 & -1.17 & 0.241 \\
\hline $\mathrm{DE}$ & -0.116046 & 0.003239 & -1.2 & 0.066 \\
\hline BPSM & 28.2273 & 24.01063 & 1.16 & 0.001 \\
\hline \multicolumn{5}{|c|}{ Panel B: Islamic MFIs } \\
\hline $\mathrm{CA}$ & 0.0232309 & 0.0085543 & 0.82 & 0.007 \\
\hline $\mathrm{PaR}$ & -0.0015109 & 0.003735 & -2.05 & 0.000 \\
\hline $\mathrm{RC}$ & 0.0001418 & 0.001766 & 0.14 & 0.222 \\
\hline $\mathrm{DE}$ & -0.0000124 & 0.0000651 & -0.19 & 0.212 \\
\hline BPSM & 12.150103 & 11.001284 & 0.3 & 0.008 \\
\hline
\end{tabular}

There is a positive relationship between capital structure measured by capital to asset ratio (CA) and finanacial performance of islamic microfinance institutions (increase in 1\% of CA corresponds to increase of ROA by $2.23 \%$ ). This relationship is statistically significant at the $5 \%$ level. The increase of capital leads to a reduction of external borrowing which increases the IMFIs performance. The capital must capture the overall safety and soudness of these institutions. It indicates the ability of an islamic MFI to absorb the expected losses. Thus, the varied composition of the IMFIs capital structure plays a crucil role in improving their financial performance.

The results reported a significant positive $(0.0914967 / P$-value: 0.000$)$ effect of the portfolio quality measured by Portfolio at Risk ratio (PaR) on the financial performance measured by Return On Asset (ROA) of conventional microfinance institutions. The $P$-value is significant in case of potential future bad debts. This measure represents the oustanding amount of all loans that have one or more installments of principal past due by a certain number of days. It is a measure of the risk to the entire portfolio that the late payments indicate. Thus, a higher percentage of the PaR ratio indicates poor loan recovery. According to these results, CMFIs in average maintain a good control of their portfolio quality and seem to significantly and positively affect their financial performance. This result implies that for 1 unit increase in PaR the financial performance of CMFIs increases in average by 0.0914967 .

On the contrary, a significant negative relationship between PaR and ROA has been reported for their Islamic counterparts. In Table 7, the regression coefficient of the PaR equals -0.0015109 and is significant at the 5\% level, which means that for 1 unit increase in PaR the financial performance of IMFIs reduces by 0.0015103 .

Finally, the results showed a significantly positive impact of the productivity of the stuff members on the financial performance of conventional and Islamic microfinance institutions.

\section{Determinants of the Sustainability of Conventional and Islamic MFIs}

Table 8 presents the estimation results of the relation among social, organizational, and financial performance and the sustainability of conventional and Islamic MFIs. 
Table 8

Determinants of the Sustainability of Conventional and Islamic MFIs

\begin{tabular}{|c|c|c|c|c|}
\hline Variable & Coefficient & Std. error & $t$-statistic & Prob. \\
\hline \multicolumn{5}{|c|}{ Panel A: Conventional MFIs } \\
\hline $\mathrm{ROA}$ & 0.043658 & 0.0104433 & 4.18 & 0.0000 \\
\hline ALBPB & 0.005379 & 0.0003719 & 1.45 & 0.148 \\
\hline ABPLO & 0.001335 & 0.0000496 & 26.94 & 0.0000 \\
\hline \multicolumn{5}{|c|}{ Panel B: Islamic MFIs } \\
\hline $\mathrm{ROA}$ & 0.018833 & 0.0218194 & 0.86 & 0.388 \\
\hline ALBPB & 0.000257 & 0.0000239 & 10.8 & 0.0000 \\
\hline ABPLO & 0.002217 & 0.0001276 & 17.38 & 0.0000 \\
\hline
\end{tabular}

To achieve their sustainability, conventional MFIs count on their financial performance. The variable indicating financial performance as measured by ROA shows a positive and significant coefficient equal to 0.043658. This ratio measures the MFI's ability to use their assets to generate returns, which reflects both the profit margin and the efficiency of the institution. The ratio of operational self-sufficiency OSS compares the revenues and expenses. Thus, following this result, it can be concluded that the more conventional MFIs reach high operating results, the more they will be able to achieve their autonomy.

The variable referring to social performance as measured by the average loan balance per borrower (ALBPB) is statistically insignificant. This variable seems to have no impact on the self-sufficiency of conventional MFIs measured by the operational self-sufficiency ratio. The average loan is the most commonly used indicator among microfinance agency rating, donors, and even investors to measure the degree of MFI outreach to poor customer segments (Bhutt \& Tang, 2001; Cull et al., 2007). Conventional MFIs affect the majority of those who are excluded from the formal financial system worldwide; this feature does not allow them to ensure the survival of the sector. This means that the customers targeted by microfinance institutions are poor, excluded, and have financing needs. Therefore, they are obliged to accept high interest rates for microcredit. Meanwhile, the number of borrowers increased in conventional MFIs, and even interests increased, due to two reasons: an external reason linked with the economic situation and the instability of exchange rates and inflation; and an internal reason, connected to the fact that conventional MFIs use the increase in interest as sort of guarantee. However, the average amount of loan per borrower (ALBPB) increases due to two reasons. The primary reason is due to the increase of the denominator, which means the increase of the number of borrowers. The second reason is the fact, with time, the high interest overwhelms these poor borrowers who will be unable to repay their obligations. Thus, conventional MFIs resort to increase the average loan amount as a means of security. Therefore, mission drift occurs when the size of the average loan increases. This indicates that an MFI has moved into new customer segments, either because it begins to include customers who are better off or because existing clients experience success and are thus able to take on larger loans. In recent years, critisims of the sector have emerged, arguig that interest rates are too high, that borrowers take on more loans than they can repay and that there is no impact on poverty alleviation. This judgement is in concordance with many other studies which claimed that the microfiannce industry is witnessing a mission drift movement (Tulchin, 2003; Yunus, 2007; Ghosh \& Tassel, 2008; Amendariz \& Szafarz, 2011; Amendariz, Despallier, Hudon, \& Szafarz, 2011; Abrar \& Javaid, 2014). Also, in concordance with the findings of Banerjee, Duflo, Glennerster, and Kinnan (2015), who were the first to randomized impact evaluation, indeed found no impact 
on poverty reduction, gender gap, health, or education. However, This conclusion could only remain in average since the database is composed of MFIs for different regions and different countries which should be taken into consideration, also the regulation status of these institutions and the recent commercialization movement, since regulated commercial microfinance institutions are in high probability of mission drift for achieving more of financial objectives.

A positive relationship (significant coefficient equal to 0.001335 ) is also recorded between operational self-sufficiency and organizational performance as measured by the "ABPLO" indicator. This allows us to say that the durability of conventional MFIs is sensitive to their organizational performance.

The empirical estimation results of the theoretical model for the sustainability of Islamic MFIs show that the financial performance measured by return on assets (ROA) does not significantly affect their operational autonomy (OSS). The coefficient of the social performance measured by the average loan balance per borrower is statistically significant with a positive sign. Although Islamic MFIs serve only a minority of the total poor in the world, this seems to be the reason for their continuity and the sustainability of the sector, serving a limited number of customers and affecting an average balance which is low compared to that of conventional MFIs, it seems to positively impact the autonomy of Islamic MFIs. This is due to the nature of Islamic financial contracts which do not overwhelm the beneficiaries. Borrowers find flexibility by engaging in this type of collaborative funding. In addition, they satisfy their needs with respecting their religious standards. On this particular point, in order to guarantee their continuity Islamic, MFIs rely on the realization of their operational performance.

\section{Conclusion}

This study deals with the emerging Islamic microfinance sector compared to conventional microfinance. Specifically, the paper studies the determinants of financial, social, and organizational performance and sustainability on a sample of 382 MFIs over a period of 17 years.

The results reveal that the number of borrowers affected by Islamic MFIs remains very low compared to their counterparts. In addition, the economic size and seniority help conventional MFIs to further improve their social performance. On the financial side, conventional MFIs rely heavily on debt and the productivity of their personnel to perform financially. However, Islamic IMFs rely rather on financial capital invested and staff productivity.

In order to guarantee their existence, Islamic MFIs show more potential in depending on the social performance compared to their conventional counterparts.

Conventional MFIs financially outperform their Islamic counterparts in their way towards sustainability. They rely on their organizational and financial performance in order to continue serving their clients.

Overall, the results provide extensive evidence on the factors that contribute to the performance and the suitability of Islamic microfinance institutions against its conventional counterparts. The Islamic law compliance and the specificity of offered financial products permit a steady increase of clients, which will result in improving social performance, and therefore ensuring their sustainability.

\section{References}

Abdul Rahim Abdul Rahman. (2007). Islamic microfinance: A missing component in Islamic banking. Kyoto Bulletin of Islamic Area Studies, 1-2(2007), 38-53.

Abrar, A., \& Javaid, A. Y. (2014). Commercialization and mission drift-A cross country evidence on transformation of microfinance industry. International Journal of Trade, Economics and Finance, 5(1), Februrary 2014. 
Adair, P., \& Berguiga, I. (2010). Les facteurs déterminants de la performance sociale et de la performance financière des institutions de microfinance dans la région MENA: Une analyse en coupe instantanée. Région et Développement, $32,92-119$.

Ahlin, C., Lin, J., \& Maio, M. (2010). Where does microfinance flourish? Microfinance institutions performance in marco-economic context. Journal of Development Economics, 95, 105-120.

Ahmed, H. (2002). Financing micro enterprises: An analytical study of Islamic microfinance institutions. Journal of Islamic Economic Studies, 9(2), 28-64.

Ahmed, H. (2007). Waqf-based microfinance: Realizing the social role of islamic finance. Paper written for the International seminar on "Intergrating Awqaf in the Islamic Financial Sector", Singapore, March 6-7. Retrieved from http://imfn.org/images/Literature/Waqf-Based Microfinance Realizing the Social Role of Islamic.pdf

Allaire, V., Ashta, A., Attuel-Mendes, L., \& Krishnaswamy, K. (2009). Institutional analysis to explain the success of moroccan microfinance institutions. Working Paper, Bruxelles: Solvay Brussels School of Economics and Management Centre Emile Bernheim, No. 09/057, p. 30. Retrieved from http://ideas.repec.org/p/sol/wpaper/09-057.html

Anand, K. R., \& Sandhya, R. (2012). Factors affecting financial sustainability of microfinance institutions. Journal of Economics and Sustainable Development, 3(6), 1-9.

Amendariz, B., \& Szafarz, A. (2011). On mission drift in microfinance institutions. MPRA Paper, No. 31041.

Amendariz, B., Despallier, B., Hudon, M., \& Szafarz, A. (2011). Subsidy uncertainty and microfinance mission drift. $C E B$ Working Paper, No. 11/014.

Ayayi, A., \& Sene, M. (2010). What drives microfinance institution financial sustainability. The Journal of Developing Areas, 44(1), 303-324.

Barlet, K. (2009). What risks does the microfinance most exposed? Banana Skins 2009 survey, No. BIM-September $22,2009$. According to: Survey "Banana Peel" on the 2009 microfinance-Confronting the crisis and change, sponsored by City and CGAP, IFSB, No. 85 .

Banerjee, A., Duflo, E., Glennerster, R., \& Kinnan, C. (2015). The Miracle of microfinance? Evidence from a randomized evaluation. American Economic Journal: Applied Economics 2015, 7(1), 22-53.

Ben Abdelkader, I., \& Ben Salem, A. (2013). Islamic vs. conventional microfinance institutions: Performance analysis in MENA countries. International Journal of Business and Social Research (IJBSR), 3(5), 219-233.

Bhutt, N., \& Tang, S. Y. (2001). Delivering microfinance in developing countries: Controversies and policy perspectives. Policy Studies Journal, 29(2), 319-333.

Boye, S., Hajdenberg, J., \& Poursat, C. (2006). Le guide de la microfinance: Microcrédit et épargne pour le développement. Paris: Edition d'Organisation, Groupe Eyrolles.

Brau, J. C., \& Woller, M. G. (2004). Microfinance: A comprehensive review of the existing literature. Journal of Entrepreneurial Finance and Business Ventures, 9(1), 1-26.

Copestake, J., Johnson S., \& Wright, K. (2002). Impact assessment of microfinance: Towards a new protocal for collection and analysis of qualitative data (Working Paper No. 7, Imp-Act University of Sussex, Brighton) (in UK).

Cull, R., Demirguç-Kunt, A., \& Morduch, J. (2007). Finanlcial performance and outreach: Aglobal analysis of leading microbanks. The Economic Journal, 117(517), 107-133.

De Crombrugghe, A., Tenikue, M., \& Sureda, J. (2008). Performance analysis for a sample of microfinance institutions in India. Annals of Public \& Cooperative Economics, 79, 269-299.

Ducroux, C. P. (2001). Sustainability conditions of microfinance institutions. Working paper, Agridoc. GRET. 12 December 2001.

Ejigu, L. (2009). Performance analysis of a sample microfinance institution of Ethiopia. International NGO Journal, 4(5), 287-298.

El Kharti, L. (2013). Déterminants de la performance financière des institutions de microfinance (IMF) au Maroc: Analyse empirique. Centre de Recherche en Economie Appliquée à la Mondialisation (CREAM). Université Paris-EST CRETEIL, Juin 2013.

El-Zoghbi, M., \& Alvarez, K. (2015). Understanding costs and sustainability of Sharia-compliant microfinance products. Focus note 101, Washington, D.C.: CGAP, February.

Epstein, M. J., Buhovac, A. R., \& Yuthas, K. (2010). Implementing sustainability: The role of leadership and organizational culture. Strategic Finance, 91(10), 41-47.

Ghosh, S., \& Tassel, E. V. (2008). A model of microfinance and miszsion drift (Department of Economics, Florida Atlantic University) (in USA). 
Gonzales, A. (2010). Is microfinance growing too fast? MIX Data Brief No. 5. Retrieved from http://www.themix.org/sites/default/files/MIX\%20Data\%20Brief\%205\%20-\%20Is\%20microfinance\%20growing\%20too\%2 0fast.pdf

Hartarska, V. (2005). Governance and performance of microfinance institutions in central and eastern Europe and the newly independent states. World Development, 33(10), 1627-1648.

Hartarska, V., \& Nadolnyak, D. (2007). Do regulated microfinance institutions achieve better sustainability and outreach? Cross-country evidence. Applied Economics, 39(10-12), 1207-1222.

Hudon, M., \& Niyongabo, E. (2009). La politique des bailleurs en microfinance. Qu'en est-il pour les zones rurales? Cahiers $d u$ CEDIMES, 3(2), 123-141.

Jebli, A. (2012). Déterminants de la Performance des Institutions de Microcrédit au Maroc: Une analyse par les données de panel (2003-2010) (Working paper, University IBN ZOHR, Agadir, Faculty of Juridical, Economic and Social sciences) (in Morocco).

Karim, N., Tarazi, M., \& Reille, X. (2008). Islamic microfinance: An emerging market niche. CGAP focus Note, 49. Retrieved from

http://www.cgap.org/sites/default/files/CGAP-Focus-Note-Islamic-Micorfinance-An-Emerging-Market-Niche-Aug-2008.pdf

Koveos, P., \& Randhawa, D. (2004). Financial services for the poor: Assessing microfinance institutions. Managerial Finance, 30(9), 70-95.

Ledgerwood, J. (1999). Microfinance handbook: An institutional perspective. Washington D.C.: The International Bank for Reconstruction and Development, the World Bank.

Luzzi, G., \& Weber, S. (2006). Measuring the performance of institutions (working paper, Geneva, High School of Management, CRAG, $\left.\mathrm{N}^{\circ} \mathrm{HES}-\mathrm{SO} / \mathrm{HEG}-\mathrm{HE} / \mathrm{C}-06 / 1 / 3-\mathrm{CH}, 16 \mathrm{p}\right)$.

Mersland, R., \& Strom, R. O. (2008). Performance and trade-offs in microfinance organizations-Does ownership matter? Journal of International Development, 20(4), 598-612.

Mersland, R., \& Strom, R. (2009). Performance and governance in microfinance institutions. Journal of Banking and Finance, $33(4), 93-120$.

Meyer, J. (2002). Track record of financial institutions in assessing the poor in Asia. ADB Research Institue Paper, No. 49.

Mohammed, K. (2011). Building a successful business model for Islamic microfinance. Global Microcredit Summit. (Commissioned Workshop Paper. November 14-17, 2011-Valladolid) (in Spain).

Nimrah, K., \& Mohammed, K. (2011). Taking islamic microfinance to scale series: Islamic microfinance challenge 2010. Washington, D.C.: CGAP, February.

Regassa, D., \& Negash, R. (2014). Outreach and financial performance of microfinance institutions in case of Seka Cokosa Woreda of Jimma Zone. Global Journal of Management and Business Research: C Finance, 14(4), 52-67.

Schreiner, M. (2002). Aspects of outreach: A framework for the discussion of the social benefits of microfinance. Journal of International Development, 14, 591-603.

Segrado, C. (2005). Case study: Islamic microfinance and socially responsible investments. Case Study Report to University of Torino. Retrieved from http://www.saa.unito.it/meda/pdf/islamicmicrofinance.pdf

Seibel, H. D. (2008). Islamic microfinance in Indonesia: The challenge of istitutional diversity, regulation, and supervision. Journal of Social Issues in Southeast Asia, 23(1), 86-103.

Seibel, H. D., \& Agung, W. D. (2006). Islamic Microfinance in Indonesia (working paper, University of Cologne, Development Research Center, No. 2006) (in Eschborn).

Séne, M. (2010). A comprehensive literature review on all current global microfinance themes (working paper, University of Quebec) (in Canada).

Shaw, J. (2004). Microentreprise occupation and poverty reduction in microfinance programs: Evidence from Sri Lanka. World Development, 32(7), 1247-1264.

Sinha, S. K., \& Agarwal, P. K. (2010). Financial performance of microfinance institutions of India. A cross sectional study. Delhi Business Review, 11(2), 37-46.

Stephens, B. (2005). Sustainability in sight: An analysis of MFIs that become sustainable. Micro Banking Bulletin, 10, $23-29$.

Tucker, G. (2001). The development of an instrument to measure the effectiveness of residence hall associations. College Park, MD: The Department of Counseling and Personnel Services, UMI No. 3035381.

Tulchin, D. (2003). Microfinance's double bottom line: Measuring social return for the microfinance industry. Seattle: Social Entreprise Associates. Retrieved from http://www.socialentreprise.net/pdfs/microfinance_education.pdf 
Venkata, V. K., \& Gupta, V. K. (2011). Analysis of performance indicators on sustenance of microfinance institutions: A comparative study of East Asian \& Pacific, and South Asian countries. Research Journal of Finance and Account, 2(3), 1-9.

Wilson, R. (2007). Making development assistance sustainable through Islamic microfinance. IIUM Journal of Economics and Management, 2(2), 197-217.

Wright, K., \& Copestake, J. (2004). Impact assessment of microfinance using qualitative data: Communicating between social scientists and practitioners using the QUIP. Journal of International Development, 16(3), 355-367.

Yunus, M. (2007). Creating a world without poverty: Social business and the future of capitalism. New York: Public Affairs Books. 